\title{
Illegal Immigrant Policy in China: Comparative Study with Australia and Canada
}

\author{
Tanjirul Islam*, Guofu Liu \\ School of Law, Beijing Institute of Technology, Beijing, China \\ Email: ^tanjir@qq.com, germany2030@163.com
}

How to cite this paper: Islam, T., \& Liu, G. F. (2020). Illegal Immigrant Policy in China: Comparative Study with Australia and Canada. Beijing Law Review, 11, 489-500. https://doi.org/10.4236/blr.2020.112030

Received: March 16, 2020

Accepted: May 17, 2020

Published: May 20, 2020

Copyright $\odot 2020$ by author(s) and Scientific Research Publishing Inc. This work is licensed under the Creative Commons Attribution International License (CC BY 4.0).

http://creativecommons.org/licenses/by/4.0/

\begin{abstract}
This paper is for seeing the illegal immigrant's situation and policy of China, comparatively with Australia and Canada; also, finding out the safeguards for the illegal immigrants within those countries' existing law and policy, but any permanent and convenient regulation as safety measure has not been found within those countries' existing law and policy for the illegal immigrants. Rather, by the pushing back and detaining action against illegal immigrants by the host countries, the life and surviving of the illegal immigrants are being upside-down, they are getting scared in every pulse of their life in the host country, even after pushing back in other countries or home country. So, for getting a stable solution, it is demand of time to invent a new process for alleviating this issue with the ensuring safe-life of illegal immigrants. Hopefully, new initiative has mentioned by this study as the benefit of this research to get release from the heavy pressure of illegal immigrants.
\end{abstract}

\section{Keywords}

Illegal Immigrant, Policy of China, Australian and Canadian Policy, Protection, Resolution

\section{Introduction}

So far, world is going into the free-trade market, the tendency of the people to be migrated in wealthy country for seeking a standard lifestyle; jointly being expanded, but sometimes the migration system is full of ambiguity and most of the people are not known well about the system that how to be migrated into other countries as legal, so they are facing the broker agency to solve their dream of being an immigrant. In this case, they are falling into a trap of the broker by the temptation of a bright life. In addition, developed countries are more intended 
to allow the people who have the skill and healthy qualification, so the person who does not have that required ability to get the permission to take entry in the destination country; he is easily being the victim as illegal immigrant, because he takes the association from the agency ${ }^{1}$ or the relative (who already living in host country) to come, or comes as tourist, then just extends the staying and tries to find job. On another hand, people are coming to the host country as student by the agency then leave the campus and do job without any work-permit, and turn into an illegal immigrant.

However, the quantum of illegal entering and staying in the host countries is enlarging rapidly; some of the countries have been the target by the people from the developing and poor countries in all over the world, such as Germany, Canada, Sweden, Malaysia, Finland, United Arab Emirates, Saudi-Arabia, Italy, United Kingdom, Spain, Australia, United States of America, and China. In this horrible situation, those countries are very strict and in hard position to face illegal immigrant, not only these countries but also other states are in solid side about illegal immigrant. For this reason, illegal immigrants all over the world are hanging on the mouth of danger. There is no security in their life and work. Though as a human being they have the right to get a safe life.

Almost all countries have immigration policy as well as illegal immigrant policy, but the protective regulation for illegal immigrant is too rare, rather have the law for deterring the illegal immigrant. Since China is now the most highlighted countries for their growing trade market and education sector, it turns into the place for the illegal immigrant; with this country, Australia and Canada are also being the first category's destination for the illegal immigrant because of those countries' healthy workplace, established economy and safe life.

So, it has chosen to make study on illegal immigrant's situation and policy of China, Australia and Canada, since those countries are being the desirable destination for migration, as well as illegal immigrant's crises are increasing. Moreover, to see whether there is any protective regulation for the protection of illegal immigrant or not; but if there is no regulation then what should be the protection for the illegal immigrant or what should be the law for giving the next safe life. If we do not do it then the permanent solution will never arise in forward. Only the hard side cannot be the accepted resolution.

\subsection{Literature Review}

"Man is naturally mobile. In every epoch, in every part of the world and in every civilization, there has been migration. Migration must not therefore be regarded as abnormal phenomenon disturbing the natural order of things. The migrants are no exception because migration is a normal part of people's individual and collective lives. This is an essential truth that is little appreciated nowadays and of which we should all become more fully aware," stated by the Organization of

${ }^{1}$ Agency means the company, which is for handling whole process in favour of a person to get visa as student or tourist by the consideration of money. 
Economic and Cooperation Development (OECD) ${ }^{2}$ in 1990.

Nowadays, the rate of the migration of the people from different countries of the world is being higher than past three decades. Basically, peoples from developing countries are intended to go to the developed states; besides, the poor countries citizens are trying to get entry into the developing and developed countries. It would have been glad issue if everything would have been legally and peacefully. The truth aspect is that the percentage of the illegal migration process is quietly higher than legal migration system.

In this era, European countries are most discussed issue because of illegal entry of the neighboring or economically poor states as well as for the refugee and asylum seekers. In this study, the illegal immigrant policy is the main agenda, and for this fact the Chinese immigrant policy has been studied comparatively with the policy of Canada and Sweden.

China is the new trend that has been attracted by the other countries' people for coming and getting social security in case of economic condition. Though because of the lack of legal processing the entry is being illegal and those people are being treated as illegal immigrant who did not follow the legal rules and regulation of the destination country.

In China, there is the fundamental law as the Exit and Entry Administration Law of China, 2013. Article 15, of this law stipulated, "In order to entering China, foreigners shall apply to the visa-issuing authorities stationed abroad for a visa, except as otherwise provided for in this Law," and article 16 has been stated as, "Visas are categorized as diplomatic visa, courtesy visa, official visa and ordinary visa. Diplomatic or official visas shall be issued to foreigners who enter China for diplomatic or official reasons; and courtesy visas shall be issued to foreigners who are given courtesy due to their special status. The scope and measures for issuing diplomatic, courtesy and official visas shall be stipulated by the Ministry of Foreign Affairs. Appropriate types of ordinary visa shall be issued to foreigners who enter China due to non-diplomatic or official reasons including work, study, family visit, travel, business activities and talent introduction. The types of ordinary visa and relevant issuance measures shall be stipulated by the State Council." Besides, article 20 of this law has been stipulated, "Foreigners who need to enter China urgently for humanitarian reasons, or are invited to enter China for urgent business or rush repair work, or have other urgent needs, and hold materials that prove the competent departments" approval of their applying for visas at port, may apply for port visas with the visa-issuing authorities entrusted by the Ministry of Public Security at the ports (hereinafter referred to as "port visa authorities") which are approved to issue port visas by the State Council. Travel agencies that organize inbound tourism in accordance with re${ }^{2} \mathrm{OECD}-$ Organization for Economic co-operation and Development, is an organization for economic co-operation in Europe, it had been constituted on 16 April, 1948. Now 20 countries are the members of OECD including Canada and United States. the European Economic Cooperation Organization, which was established on April 16, 1948 by more than ten countries in Western Europe, within December 14 of 1960, a total of 20 countries have been engaged there, including Canada; and United States. 
levant State regulations may apply for group tourist visas from port visa authorities. So, if anyone who is the citizen of overseas does not carry that kind of visa and living in China then he or she shall be treated as illegal immigrant in China.

By the different books and scholarly articles by Chinese immigration scholars, it has expressed that China is thinking about the over flow of the migrants as well as the illegal migrants. Moreover, China is now jointly working with the International Organization of Migrants (IOM). However, the illegal immigrant policy of China is convenient yet for the illegal immigrant in China? This is a question, because most of the tasks by China with IOM are for reducing the illegal immigrant not for the protection thereby.

On another hand, in Australia the immigration system is totally separated from China and Canada. For getting entry in Australia sponsorship is the most expecting option for the immigration seekers in Australia; moreover, Australia is the country which is introducing the E-Visa for visiting in one-year period for maximum three months per entry without any processing fee. Also, working visa, student visa, tourist visa, joint-partner visa, refugee and humanitarian visa; and to avoid illegality of an immigrant, bridging visa has introduced as well. In case of entering through tourist visa, joint-partner visa and sponsor are the main pipes for continuing staying as illegal immigrant in Australia. In this way, law of Australia is very strict and rigid for the illegal immigrants, but the quantum of research on this issue to find out the cheaper and convenient way for the illegal immigrants is very limited.

Finally, for finding the protecting view or policy for the illegal immigrant in Chinese, Australian and Canadian immigration policy, this study has done.

\subsection{Research Methodology}

The view of this research is on the illegal immigrant policy of China and comparative study with the policy of Australia and Canada. By this study the protective essence of the policy is the finding factor for the illegal immigrant in those countries' migration law. Though those countries have the separated immigration policy, finding the specific structure of law in those countries' policy for the illegal immigrant is not expressive thereby. However, conducting this research method is analytical, and study is based on the primary evidence, such as statutes, enacted rules for migration policy, etc. Moreover, the secondary evidence, such as journal articles, books, websites and the scholarly comments by the experts of this field.

\section{Illegal Immigrant's Consequence and Existing Law in China}

\subsection{Chinese Migration System}

China's migration system is conducting mainly under the Exit and Entry Law of China (EEA), 2013, calls in Chinese as Chujing Rujing Guanli Fa, it had been promulgated in June, 2012 and have come out for obeying in July of 2013, 
though there is no one comprehensive code as immigration law. From the last few decades, China has undergone significant political, economic and demographic changes that have been transformed the patterns of migration to and from the country. China is now a popular destination country for the immigration of different country's people. In 1990, there were about 20,000 foreigners in China. At the last of 2010, nearly 600,000 foreigners who had come for business and study purposes, were living by the estimation of the Chinese National Bureau of Statics (NBS). From the data of Chinese National Bureau of Investigation, It was announced that 57 percent of foreigners were males and 43.3 percent were females. Most of them have come from the Republic of Korea, nearly 12,750 , nearly 71,493 from the United States and 66,159 from Japan. Though most foreigners are long-term residents, and according to 2010 data, it was almost 67 percent. Foreigners are very attracted to Beijing, Shanghai, Nanjing, Shenzhen, Jiangsu, Chongqing, Harbin, Guangzhou, etc., provinces and cities of China for living or staying in short time and long-time basis. By this, China is also being the destination for the illegal immigrants (Liu, 2017) ${ }^{3}$.

China's immigration administration is constituted by the concurrence of the Ministry of Public Security, Foreign Affairs, Education, Economy, Human Resources and Social Security, Civil Affairs, Overseas Chinese Office, State Council, Foreign Expert Administration, China National Tourism Administration, Communist Party of China's Central Committee Department, Inter-Ministerial Coordination Mechanism, Inter-Ministerial Foreign Coordination Mechanism (Liu, 2017) ${ }^{4}$.

Generally, China allows entry visa for 30 days then have to apply for temporary permanent resident for one year, in next fulfilling the requirement for getting Permanent Resident (PR), one can apply for PR. China now is highly attracting foreign talents, businessman, employee with high salary (50,000 RMB per month), for giving permanent resident further nationality on the basis of fulfillment of condition in living period in China. Also, the student can extend their temporary resident permit on the basis of changing the visa status for work permit, also marriage migration is another one by tying a knot with Chinese citizens.

\subsection{The Causes to Be Treated as Illegal}

Since there is a rule for applying to take entry into the host countries, so when the entry does happen without noticing the instruction or condition or after entering, migrants do not follow the process for extending his validity, it normally takes to one into the immigration of illegality in China almost like other countries. Some reasons could be mentioned, i.e., 1) entering by trespassing through the smuggling way, 2) taking entry as student but doing job without work-permit, 3) extending the staying by making forgery documents, 4) coming from neigh-

${ }^{3}$ Liu, G. F. (2017). Class Lecture on International Immigration in China, available at https://max.book118.com/html/2018/0105/147486205.shtm, accessed on 4 December, 2019. ${ }^{4}$ Ibid. 
bourhood countries as relative by travel visa, but living with relative as household associate or work place-associate, 5) coming as seasonal worker, but did not extend the living validity because of proof of document from the company (who invited for short time basis, but did not allow after ending the period), 6) getting marry with the Chinese after coming as worker from neighbourhood regions (Taiwan, Vietnam, Korea, Philippines, Indonesia, Laos, Myanmar), but did not registry the marriage yet continuing the living after invalidity of the visa period, and 7) entering by tourist visa but doing job in familiar one's place by hiding the real name and identification, etc. Illegal immigration is officially called as Sanfei in China.

\subsection{Flow of the Illegal Immigrants in China}

As it has been said before, China is new dresamy destination for being migrated, but the door is not open for all, though students are coming more by agency or foreseer relative or by the broker student ${ }^{5}$ as easily for the consideration of money, most of these students then find job without work permit. However, illegal immigrants flow is being overflown than the past two decades in China. In 1995, the estimated cases of illegal immigrant issue were 10,000, but it was double as 20,000 in 2011. In the year of 2016, almost 2705 cases were filed newly. It is difficult to say that how many illegal immigrants are now living in China, because the crackdown was conducted in, 2012 for 100 days in Beijing, also in other provinces police arrested the illegal immigrants by the crackdown project in 2015, but it not less than the amount of illegal immigrant before 8 years ago.

\subsection{Principle of China on Existing Illegal Immigrants}

China is not in the soft mode in the regard of existing of illegal migrants, the principle of China in this regard is to just detain the person who does not have the legal validation to live. Almost in every year police are conducting operation for hunting the illegal immigrant in different provinces, according to the law the detainee can pursue legal association by a lawyer in favor of him, in this case discretionary power is on the Public Security Bureau, it considers the issue whether detainee can get reconsideration for staying in China or not.

\subsection{Level of the Sanction in China}

The Exit and Entry Administrative Law, 2013 (EEA) provides the administrative penalties but not the Judicial Penalties. If any employee of the work place as illegal then he has to pay 20,000 RMB as fine and 15 days imprisonment, and agency has to pay 50,000 RMB as fine, also $5000 \mathrm{RMB}$ for the employer for fraudulency. About all of the cases the detained illegal immigrants are being sent back to his or her home country. If any illegal immigrant as arrear to his employee then until the payment of that arrear he or she cannot be gone away or sent back to home country after being arrested as illegal immigrant.

${ }^{5}$ Who has come for studying but taking out more students for the money by immoral influence at admission centre of the College or University. 


\section{Status of Australia in the Regard of Illegal Immigrant}

\subsection{Comparative Influence of Illegal Immigrants in Australia}

It is well known that Australia was included in Britain, then when it had been decolonized from the United Kingdom, the Government of Australia had made a policy to give convenient entry to the immigrants for making country as wealthy by the contribution of immigrants in different sectors. In 1950, almost double of thousand people got immigration. From the time of independence Australia did not face in inter-collision, and its growth in economics and technology is being continued, so it has been succeeded to give surety of a standard environment for work and living, as a result the flows of immigration has been wider. In this way it had been turned into a dreamy place for the illegal immigrants from other countries to seek a safe place to sustain from the punishment of leaving countries where they were illegal. In the organising time of Australia, it was not in tight position for illegal immigrants, because it was feeling the demand of more labours to keep contribution in Australia's sustainable development (Australia's Policy towards Illegal Immigrants, 2013). ${ }^{6}$

However, since people got better amenities in Australia, so the flow of illegal immigrant has been expanded day by day, now it has been turned into a remarkable concern for Australia. The report of the Australian Bureau of Statistics (ABS), shows that the maximum amount of are living in Australia whose visa already been expired, but they are extending their stay in there as illegal immigrants (Australian Bureau of Statistics, 2001). ${ }^{7}$ An estimation of the Department of Immigration and Citizenship of Australia, shown that from 1 July, 2009 to 30 June, 2010, totally 15,800 people had overstayed their visas. In June of 2010, another estimation showed that about 53,900 visas had been overstayed (Overstayers and Other Unlawful Non-citizens, 2012) ${ }^{8}$. In 2017, the Daily Mail (UK based Newspaper) exposed by a news report that about 64,000 illegal immigrants are living in Australia, and one person living for 40 years as illegal immigrant who has avoided the authorities within this time, and now Malaysians are the top as illegal immigrants. According to the Australian Department of Home Affairs, between 2016 and 2017 alone, 10,000 Malaysians had overstayed, followed by about 6500 people from China and 5000 from the US. British backpackers had previously topped the list. Australian Immigration authorities said more than two thirds of the total figure came to Australia on legal visas, but continued to live on for more than two years after their visas expired.

\subsection{Discipline of Australia in This Condition}

In Migration Act 1958, illegal immigration has been determined by separating the immigrants into two groups, 1) unlawful non-citizens and 2) lawful ${ }^{6}$ Australia's Policy towards Illegal Immigrants (2013). Accurate Essays, available at http://www.accurateessays.com/samples/australias-policy-towards-illegal-immigrants/, accessed on 17 December, 2019.

${ }^{7}$ Australian Bureau of Statistics (2001). Population Growth: Coming to Australia.

${ }^{8}$ Department of Immigration and Border Protection, Australia (2012). Fact Sheet 86-Overstayers and Other Unlawful Non-citizens. 
non-citizens (Section 14, Migration Act, 1958) ${ }^{9}$. Australian immigration authority is now the Department of Home Affairs, before it was in jurisdiction of Department of Immigration and Citizenship (DIAC) and the Department of Immigration and Border Protection, respectively (Illegal Immigration to Australia, $2019)^{10}$. Australia conducts immigration detention facilities within the country, and different shore side processing units. Serco (UK based company) is on charge to administer all of the detention processes in favour of the government of Australia. Nowadays, Australia is conducting three going coastal centres with ten detention cores on the continent. Nauru, Christmas Island, and Manus Island are joined by a number of Australian resettlement detention centers. Before 1992, the Migration Act, 1958 recognized unlimited imprisonment of illegal non-citizens. In 1992, in response to a surge of boat parts from Indochina, the government showed a system of mandatory detention (Phillips \& Spinks, 2013) ${ }^{11}$.

In Migration Act, 1958, Division 2 of Part II have given the power to the authority to obtain information and documents unlawful non-citizens for taking actions; section 189 (1) of Division 7 have been said that "If an officer ${ }^{12}$ knows or reasonably suspects that a person in the migration zone (other than an excised offshore place) is an unlawful non-citizen, the officer must detain the person". Section 191 has said about ending detention on basis of fulfillment of some conditions, also section 195 has included a chance for the detainee to apply for visa, for instance bridging visa; and the minister has the discretionary power to grant visa. Section 196 introduces the duration of the detention, the detention will be continued till the removing from Australia, deportation under section 200, or granting a new visa.

Though the detention in offshore centres is being criticized, because of the lack of safety, sexual violence, health-risk, etc., however, the Australian policy has been complemented by some countries' law makers, because Australia has put the chance for illegal immigrants to apply for bridging visa in period of their judicial process of the substantive visa.

\section{Canada and Illegal Immigrant}

\subsection{Situation in Canada over Illegal Immigrants}

Canada is on top in the ranking for the immigration at this moment, it is attracting the people to be immigrated by the application of some categories, e.g., skilled migration scheme, Express Entry, sponsorship, provincial nominees, etc., on the other hand, the amount of the illegal living or staying is extended as well. In Canada, by the word of illegal treats also to one who have passed the border of Canada for getting refugee or asylum status until proving the position or get${ }^{9}$ Section 14, Migration Act, 1958.

${ }^{10}$ Illegal immigration to Australia, Wikipedia, available at, https://en.wikipedia.org/wiki/Illegal_immigration_to_Australia, accessed on 17 December, 2019.

${ }^{11}$ Phillips, J. \& Spinks, H. (2013). Immigration detention in Australia, Social Policy Section, Parliamentary Library.

${ }^{12}$ Officer means a member of Australian Defence Force. 
ting the status by the authority, Nonetheless, under the Immigration and Refugee Protection Act of 2002, any person seeking entry to Canada have to appear without delay at the near adjacent entering-port (Grant, 2018) ${ }^{13}$. Accessing a port of passage outside Canada is an unlawful act, in this case, crossing charges remain while the claim of an entrant is being prepared under section 133 of IRPA. In the case of displaced person status being awarded by the Canadian government, all fines will remain forever and claimants can face other charges (Illegal Immigration to Canada, 2019) ${ }^{14}$.

Immigration and Refugee Protection Act (IRPA), is the key Act in this issue, which established in 2003, outlines the ruling, laws, and procedures associated with immigrants within Canada. It provides officers of the Canada Border Services Agency (CBSA) with the authority to detain the person if anyone violates the rulings of the Act. From January 2017 to March 2018, the Royal Canadian Mounted Police intercepted 25,645 people crossing the border into Canada illegally. Public Safety Canada estimated that another 2500 came across in April 2018 for a total of just over 28,000, of which 1000 had been removed from Canada.

\subsection{Canada's Policy}

According to the Canada Border Services Agency (CBSA) ${ }^{15}$, anyone found to be living in Canada illegally will first be issued a removal order and then deported from the country. If an individual appeals a removal order, the deportation cannot take place until the appeal has been decided. In 2013, the numbers of illegal immigrants were almost 35,000 to 120,000 by a report of the Daily Toronto Sun. Though comparatively the illegal immigration policy of Canada is not so tight like other developed countries. Only after enactment of 1947 Citizenship Act, the legality and illegality of the living persons in Canada has been introduced (What Happens to Illegal Immigrant in Canada, 2019) ${ }^{16}$. Canada is not intended to give the reconsideration chance to illegal immigrants. The IRPA, Canada's current immigration Act, does not allow the illegal access to Canada's territory, it was an attempt to balance Canada's tradition of welcoming newcomers and protecting refugees with tougher enforcement measures meant to strengthen national security and public safety, which conveys that Law in Canada is to deny the living of the illegal immigrants. In Canada, the Canada Border Services have their tip line: 1-800-461-9999, they do investigation and see deport anyone who is working illegally.

\footnotetext{
${ }^{13}$ Grant, T. (2018). Are asylum seekers crossing into Canada illegally? A look at facts behind the controversy, The Globe and Mail.

${ }^{14}$ Illegal immigration to Canada, Wikipedia, available at

https://en.wikipedia.org/wiki/Illegal_immigration_to_Canada, accessed on 4 December, 2019.

${ }^{15}$ The Canada Border Services Agency (CBSA), was created as a standalone enforcement agency that parsed most of the enforcement role away from Citizenship and Immigration Canada (CIC).

${ }^{16}$ What Happens to Illegal Immigrant in Canada? Reference, available at

https://www.reference.com/government-politics/happens-illegal-immigrants-canada-107f166da99ce

7e4, accessed on 4 December, 2019.
} 


\section{Searching the Safeguards for the Illegal Immigrant in Those State's Policy}

It is now almost clear that each of the country's main intention is to make their country as free from the unexpected pressure of illegal immigrants, it is not wrong step by those countries for ensuring public security in each of the country, but objection is that it should not be just eliminating without giving any rebate to be integrated in the host country, or excepting ensuring a safe and meaningful repatriation in home country. Though it can become out by the destination that it is not our duty to ensure facilities for illegal person, because we did not welcome ever to come in illegal way or to be illegal in our country; but according to Article, 13 of the Universal Declaration of Human Rights that, "everyone has the right to freedom of movement and residence within the borders of each State and everyone has the right to leave any country, including his own, and to return to his country." In this case it expresses the free-migration, then why country is taking a conservative way to allow the foreigner only on the basis of requirement, not for unskilled poor worker? And why they are not taking initiative to stop the activities of the broker and agency? who basically tempts the poor people to be migrated or show the way to be illegal by escaping or hiding name and identity in host country after the validity of the visa. Then the host countries have some duties in case of the morality of the customary international law. Since those country's policy is different according to their social, economic and political aspects. China is a large country, it has vast population, so to secure its social life it cannot be so tolerable for illegal immigrants. In contrast, Australia and Canada are balanced in their population; so those countries might be protective of the illegal immigrants compare to China. In Chinese, Australian, and Canadian existing law and policy, there is no convenient safe uard for the illegal immigrants, though Australia has put a chance to apply for a visa in the time of detention, and in judicial period an illegal immigrant can apply for a bridging visa; but those are not convenient for the illegal immigrant, because managing documents and hiring a lawyer or an agent in that crucial period is so difficult and time consuming also expensive. It will be great step if countries take initiative to stop the ways those are liable for making illegal immigrants

\section{Protection for the Illegal Immigrant as Recommendation}

Since, in country's law the protection for illegal immigrants is not assured or touched thereby. For this reason, it is a demand of bitter reality to create a surviving approach for illegal immigrants not only in these countries but also all over the world. It could be, 1) arranging a convention to make a new covenant among the countries for safe and meaningful repatriation, 2) amending the existing policies of the countries for keeping the reconsideration chance on the basis of previous record of the illegal immigrant, 3) controlling and monitoring to the private agencies activities for assisting to get travel and work visa, 4) forbidding the private agencies activities to get visa for the person below 25 years, 5) 
forbidding the total activities of the private agency and broker for handling student visa process in favour of others, 6) cancelling the studentship, who admits the student without blood relation for the consideration of money, 7) not giving the travel visa, without the sponsor or the business purpose, or the 15 lakhs savings in own active bank account (showing the one year active transaction documents for 1.5 lacs from the same account of same name), 8) arranging reconsideration year for the illegal migrants on the basis of non-criminal activities, for others arranging safe repatriation, 9) if any one does criminal offense or offence under tort liability law shall be punished (judicial penalty and elimination from the reconsideration system on basis of actual proof of offense).

Without taking protective measures in the law it is not possible to eradicate the problem of illegal immigrants.

\section{Conclusion}

The illegal immigrant's situation of China, Australia and Canada is being a dismal issue and the policy is being tightened for reducing the flow of the immigrants and to show scare to the living illegal immigrants, but not basic regulation to prevent the way of being illegal immigrants; further the safeguards for the existing illegal immigrants are not mentioned within the existing policy that is actually emergent to give chance to the illegal immigrants to be legal. After all, without mutual rebate among countries' policy on the basis of the social view, no country can solve this crisis of illegal immigrants. It is not the issue to overcome in a short time; the legislature could be agreed that the development of migration policy needs a longer time to become an unbroken organ of a wholly domestic and international perspective in financial and social policy (Liu, 2007) ${ }^{17}$. Man has the intention to be migrated to other countries, which is natural like other animal's life, for example, birds from the snowy region come to the tropical region for getting a comfortable zone. In this way people want to go to a country wealthier than his or her country for maintaining a healthy lifestyle. It should not be interrupted by the obscure policy of the developed country; in another without stopping the broker and private agency's unfair activities, the rich country cannot be free from the flow of illegal immigrants and the world will not be able to protect the life of human beings from being thrown in the sea.

\section{Acknowledgements}

For sincere cooperation, special thanks go to LV Sixuan, Associate Professor of Law, Tianjin University, Tianjin, China.

\section{Conflicts of Interest}

The authors declare no conflicts of interest regarding the publication of this paper.

${ }^{17}$ Liu, G. F. (2007). The Right to Leave and Return and Chinese Migration Law. Martinus Nijhofi Publishers, p. 323. 


\section{References}

Australia's Policy towards Illegal Immigrants. Accurate Essays. http://www.accurateessays.com/samples/australias-policy-towards-illegal-immigrants

Australian Bureau of Statistics (2001). Population Growth: Coming to Australia. Canberra: Australian Bureau of Statistics.

Department of Immigration and Border Protection, Australia (2012). Fact Sheet 86-Overstayers and Other Unlawful Non-Citizens. Belconnen: Department of Immigration and Border Protection, Australia.

Grant, T. (2018). Are Asylum Seekers Crossing into Canada Illegally? A Look at Facts behind the Controversy. The Globe and Mail.

Illegal Immigration to Australia. Wikipedia.

https://en.wikipedia.org/wiki/Illegal_immigration_to_Australia

Illegal Immigration to Canada. Wikipedia. https://en.wikipedia.org/wiki/Illegal_immigration_to_Canada

Liu, G. F. (2007). The Right to Leave and Return and Chinese Migration Law. Leiden: Martinus Nijhoff Publishers.

Liu, G. F. (2017). Class Lecture on International Immigration in China. https://max.book118.com/html/2018/0105/147486205.shtm

Phillips, J., \& Spinks, H. (2013). Immigration Detention in Australia, Social Policy Section, Parliamentary Library.

What Happens to Illegal Immigrant in Canada? https://www.reference.com/government-politics/happens-illegal-immigrants-canada-1 07f166da99ce7e4

\section{Appendix}

\section{Statutes}

1) The Exit and Entry Administrative Law of China, 2013

2) The Immigration and Refugee Protection Act, 2002

3) The Migration Act, 1958 